DOI: $10.2478 / \mathrm{v} 10025-008-0008-\mathrm{z}$

JOURNAL OF WATER

AND LAND DEVELOPMENT

J. Water Land Dev. No. 11, 2007: 91-102

\title{
Assessment of water pollution by nitrates in the Middle Odra Basin
}

\author{
Agnieszka KOLANEK, Rafalina KOROL, Marzenna STROŃSKA, \\ Urszula SZYJKOWSKA
}

Institute of Meteorology and Water Management, Wrocław Branch, Parkowa 30, 51-616 Wrocław, Poland; phone: +48 (71) 328-56-44, e-mail: Zaklad.Monitoringu@imgw.wroc.pl

\begin{abstract}
The objective of the study was to characterise the quality of surface waters in order to determine their vulnerability to pollution by nitrogen compounds from agricultural activity, as well as to specify the areas with increased exposure, where nitrogen runoff from agricultural sources has to be reduced. It was necessary to determine surface waters liable to pollution by these compounds due to the fact that agricultural production should be carried out in the way which limits and prevents water pollution by nitrogen compounds of agricultural origin. The study addressed the following issues: the concentration of nitrogen compounds in the surface waters of the Middle Odra Basin, and the extent of eutrophication in flowing inland waters (with nitrogen as the main nutrient). The results have been plotted in figures and gathered in tables.
\end{abstract}

Key words: eutrophication, nitrate, Odra River Basin, water quality

\section{CHARACTERISATION OF THE AREA}

In terms of length, the transboundary river Odra is the sixth longest river discharging into the Baltic Sea. In fact, the length of the river has not yet been defined unequivocally. According to the Report by the International Commission for the Protection of the Odra against Pollution (ICPO) (Report..., 2004), the total length of the Odra is $854.3 \mathrm{~km}$ (Podział..., 1983). The ICPO has not unified the riverkilometre on the Polish and Czech sides: the one in force dates from 1825 (Oder-Auen-Atlas, 2000) but the figures in Poland differ from relevant figures on the Czech territory. The Polish part of the transboundary river Odra is $741.9 \mathrm{~km}$ long, of which a $161.7 \mathrm{~km}$ stretch marks the boundary between Poland and Germany (Podział..., 1983).

The total area of the International River Basin District Odra (together with the Szczecin Lagoon and its tributaries) covers $122,512 \mathrm{~km}^{2}$. The Odra Basin area that extends from the source to the Szczecin Lagoon encompasses $118,861 \mathrm{~km}^{2}$, of 
which $106,812 \mathrm{~km}^{2}$ are part of Poland's territory; $6,453 \mathrm{~km}^{2}$ and $5,587 \mathrm{~km}^{2}$ belong to the Czech Republic and the Federal Republic of Germany, respectively (Report..., 2004). Geographically, the Odra Basin is divided into four areas: the source area of the Odra, the Upper Odra, the Middle Odra and the Lower Odra. In Poland, for the needs of water management, the Odra Basin has been divided into four water regions: the Upper Odra, the Middle Odra, the Warta, and the Lower Odra. In its Report for the European Union, the ICPO has established a division into six subbasins: the Upper Odra, the Middle Odra, the Nysa Łużycka, the Warta, the Lower Odra and the Szczecin Lagoon (Table 1) (Report..., 2004).

Table 1. Differences in the division of the International River Basin District Odra

\begin{tabular}{|c|c|c|c|}
\hline $\begin{array}{l}\text { Division } \\
\text { of the basin }\end{array}$ & Name of the basin & Area under study & $\begin{array}{c}\text { Surface area } \\
\mathrm{km}^{2}\end{array}$ \\
\hline \multirow{4}{*}{$\begin{array}{l}\text { Geographical, } \\
\text { according to } \\
\text { Atlas (Oder- } \\
\text { Auen-Atlas, } \\
2000 \text { ) }\end{array}$} & source area of the Odra & from source to the Olza (inclusive) & 5842 \\
\hline & Upper Odra & from the Olza to the Widawa (inclusive) & 18600 \\
\hline & Middle Odra & from the Widawa to the Warta & 29094 \\
\hline & Lower Odra & $\begin{array}{l}\text { from the Warta (inclusive) to the Szczecin } \\
\text { Lagoon }\end{array}$ & 65325 \\
\hline \multirow{4}{*}{$\begin{array}{l}\text { According to } \\
\text { regions for the } \\
\text { needs of water } \\
\text { management in } \\
\text { Poland (Roz- } \\
\text { porządzenie } \\
\text { RM, 2002) }\end{array}$} & Upper Odra & from source to Koźle & 9173.6 \\
\hline & Middle Odra & from Koźle to the Nysa Łużycka (inclusive) & 42530.1 \\
\hline & Warta & from source to confluence to the Odra & 54528.7 \\
\hline & Lower Odra & $\begin{array}{l}\text { from the Nysa Lużycka to the Szczecin } \\
\text { Lagoon (without Warta) }\end{array}$ & 12628.6 \\
\hline \multirow{6}{*}{$\begin{array}{l}\text { According to } \\
\text { the subbasins } \\
\text { established for } \\
\text { the ICPO Re- } \\
\text { port (Report..., } \\
2004 \text { ) }\end{array}$} & Upper Odra & from source to the Nysa Kłodzka (inclusive) & 18000 \\
\hline & Middle Odra & $\begin{array}{l}\text { from the Nysa Kłodzka to the Warta, } \\
\text { without Nysa Lużycka }\end{array}$ & 31239 \\
\hline & Nysa Łużycka & Nysa Łużycka Basin & 4297 \\
\hline & Warta & Warta Basin & 54528 \\
\hline & Lower Odra & from the Warta to the Szczecin Lagoon & 10797 \\
\hline & Szczecin Lagoon & coastal waters with Szczecin Lagoon & 3651 \\
\hline
\end{tabular}

The area under consideration is that of the Middle Odra as presented in the ICPO Report. The total surface area amounts to $31,239 \mathrm{~km}^{2} .51 \%$ of the area are utilised for agricultural purposes (arable land, 40.5\%; orchards, 0.3\%; meadows, 6.7\%; pastures, 3.5\%), and 29.3\% are forested (KOROL et al., 2002).

In this area the Odra has the following tributaries: 7 small rivers (Table 2) and 12 small streams. In 5 river basins (Oława, Bystrzyca, Kaczawa, Obrzyca and Bóbr) 71 water intakes for municipal supply systems have been established. They serve a population of about 1,412,600, including large agglomerations: Wrocław, Legnica and Zielona Góra (KOROL et al., 2003).

Water quality has been monitored by 53 stations since 1998 (Fig. 1). 
Table 2. Characterisation of the tributaries of the Middle Odra

\begin{tabular}{l|l|c|c|c}
\hline $\begin{array}{c}\text { Name } \\
\text { of tributary }\end{array}$ & Position & $\begin{array}{c}\text { Length } \\
\mathrm{km}\end{array}$ & $\begin{array}{c}\text { Basin area } \\
\mathrm{km}^{2}\end{array}$ & $\begin{array}{c}\text { Km } \\
\text { of confluence }\end{array}$ \\
\hline Oława & left & 91.7 & 1167.4 & 250.4 \\
Bystrzyca & left & 95.2 & 1767.8 & 266.5 \\
Widawa & right & 103.2 & 1716.1 & 266.9 \\
Kaczawa & left & 83.9 & 2261.3 & 315.9 \\
Barycz & right & 133.0 & 5534.5 & 378.1 \\
Obrzyca & right & 65.7 & 1808.4 & 496.4 \\
Bóbr & left & $269.6^{1)}$ & $5829.8^{1)}$ & 516.2 \\
\hline
\end{tabular}

${ }^{1)}$ Within the boundaries of Poland.

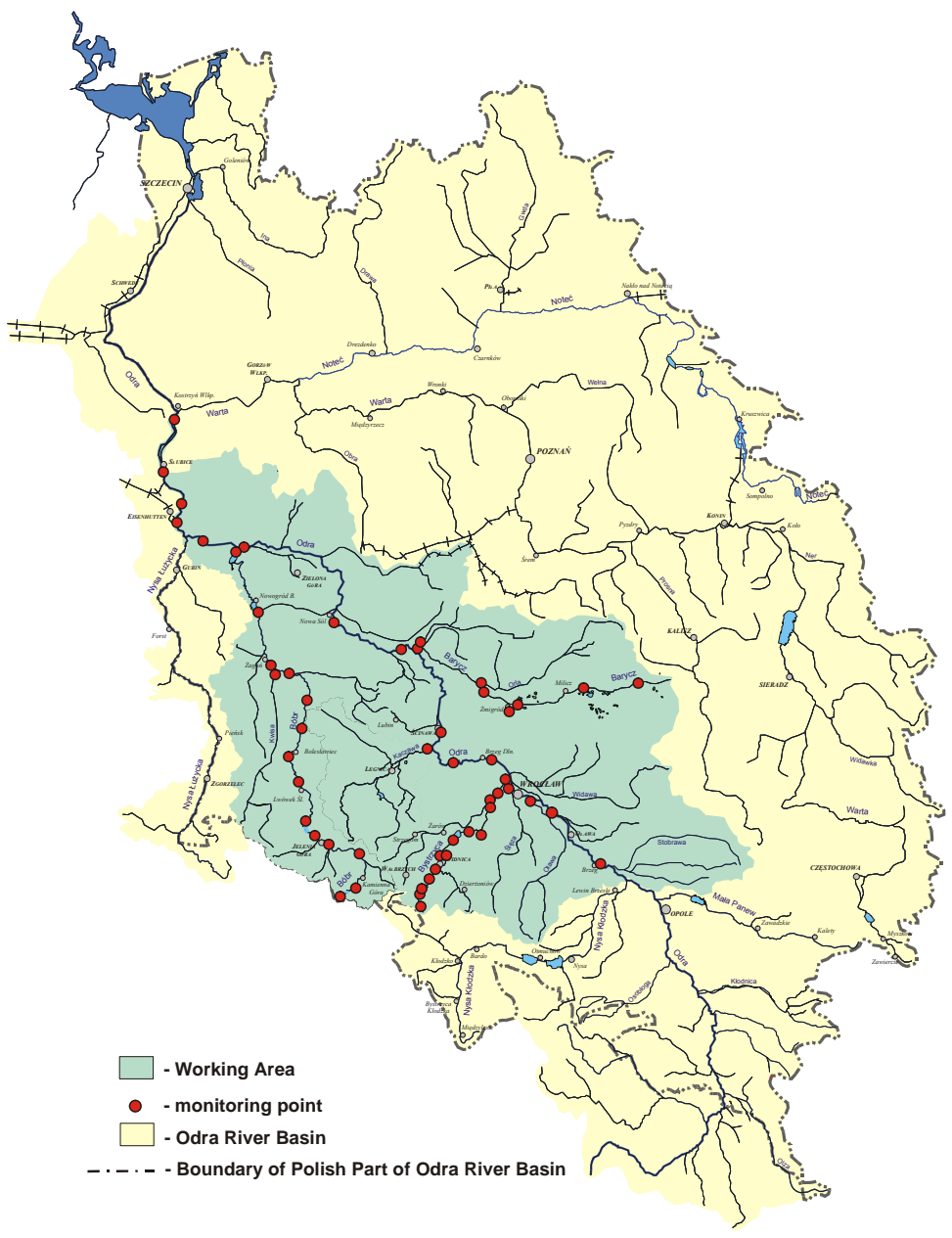

Fig. 1. Map of the Middle Odra with monitoring stations 


\section{SCOPE AND METHODS}

The need to implement EU legislation as a result of Poland's access to this Community has necessitated the following actions: assessing the levels of riverine water pollution by nitrates, specifying the watercourses vulnerable to pollution by nitrogen compounds, and defining areas of particular vulnerability, where nitrogen discharge from agricultural sources should be reduced.

In the study reported in this paper use a data set was used from the monitoring stations investigated in the years 1992-2003. With the results collected in the data base it was possible:

- to assess (in terms of time and space) the occurrence of concentrations that did not exceed the limit values for tap water according to Directive 75/440/EEC (Council Directive, 1975) and Polish recommendations (Rozporządzenie MŚ $\mathrm{z}$ dnia 27 listopada $2002 \mathrm{r}$.): $25 \mathrm{mg} \mathrm{NO}_{3} \cdot \mathrm{dm}^{-3}$ and $50 \mathrm{mg} \mathrm{NO}_{3} \cdot \mathrm{dm}^{-3}$, respectively, and to classify the levels of pollution with nitrates in the monitored waters as (Rozporządzenie MŚ z dnia 23 grudnia 2002 r.):

- high purity waters, $\leq 25 \mathrm{mg} \mathrm{NO}_{3} \cdot \mathrm{dm}^{-3}$,

- clean waters, $>25-\leq 40 \mathrm{mg} \mathrm{NO}_{3} \cdot \mathrm{dm}^{-3}$,

- waters vulnerable to pollution, $>40-\leq 50 \mathrm{mg} \mathrm{NO}_{3} \cdot \mathrm{dm}^{-3}$,

- polluted waters, $>50 \mathrm{mg} \mathrm{NO} \cdot \mathrm{dm}^{-3}$;

- to analyse the trends of variations in the maximum concentrations of nitrates in the Middle Odra Basin in 1992-2005;

- to assess the extent of eutrophication in the investigated riverine water;

- to assess the monitoring programme developed so far and the one recommended by the Water Framework Directive (Directive 2000/60/EC) and Nitrates Directive (Council Directive 91/676/EEC) in order to find out whether it will suffice for calculating the annual loads at the "closing" stations of subbasins or water bodies.

Under Polish regulations (Rozporządzenie MŚ z dnia 23 grudnia 2002 r.) the notion 'waters vulnerable to pollution with nitrogen compounds from agricultural sources' includes polluted waters and waters vulnerable to pollution if no measures are taken to reduce direct or indirect discharge of nitrates and other agriculturerelated nitrogen compounds that may convert into nitrates.

The extent of pollution was determined by analysing the plots of maximal nitrate concentrations along the watercourse and specifying the waters vulnerable to pollution and those polluted with nitrates. The extent of eutrophic and noneutrophic waters was also determined in the profiles, taking into account the average concentrations of nitrates, total nitrogen, total phosphorus, and chlorophyll $a$ (Podział..., 1983).

Eutrophication was assessed based on criteria included in the Decree of the Minister of Environment (Rozporządzenie MŚ z dnia 23 grudnia 2002 r.) (Table 3). 
Table 3. Threshold values of basic water eutrophication parameters (in case of excess, eutrophication occurs)

\begin{tabular}{l|l|c|c|c|c}
\hline \multicolumn{1}{c|}{ Parameter } & Unit & $\begin{array}{c}\text { Lake water } \\
\text { (vegetation } \\
\text { season) }\end{array}$ & $\begin{array}{c}\text { River water } \\
\text { (mean annual } \\
\text { concentration) }\end{array}$ & $\begin{array}{c}\text { Transitional } \\
\text { water }\end{array}$ & $\begin{array}{c}\text { Coastal } \\
\text { water }\end{array}$ \\
\hline Total phosphorus & $\mathrm{mg} \mathrm{P} \cdot \mathrm{dm}^{-3}$ & $>0.1$ & $>0.25$ & $>0.3$ & $>0.1$ \\
Total nitrogen & $\mathrm{mg} \mathrm{N} \cdot \mathrm{dm}^{-3}$ & $>1.5$ & $>5$ & $>7$ & $>4$ \\
Nitrates & $\mathrm{mg} \mathrm{NO} \cdot \mathrm{dm}^{-3}$ & - & $>10$ & $>15$ & $>8$ \\
Chlorophyll $a$ & $\mu \mathrm{g} \cdot \mathrm{dm}^{-3}$ & $>25$ & $>25^{1)}$ & $>50 />30^{2)}$ & $>10$ \\
\hline
\end{tabular}

${ }^{1)}$ Refers to rivers of a water residence time sufficiently long for algal growth.

${ }^{2)}$ In the section near the Odra estuary $>50$; in the near-estuary of other basins $>30$.

In our study we used the results obtained by the laboratories of the Environment Protection Inspectorates of the Lower-Silesian and Lubuskie voivodships. Analytical methods and research programmes were in compliance with the regulations of the National Environmental Monitoring System.

In the years 1992-2003, the national river monitoring programme underwent some changes, which included, inter alia, the number of stations and the frequency of analyses. Till 1997 analyses were carried out twice a month and since then sampling has been carried out once a month. Thus, over the period of 11 years, the number of nitrate analyses totalled 13,838 and the size of the set decreased from 2434 in 1992 to 643 analyses in 2005. Over the entire time period of interest, nitrates were determined with a frequency of no less than once a month, which complies with the frequency recommended in the Council Directive 91/676/EEC. The analytical method for determining nitrates in water bodies included in the Polish standard PN-87/C-04576/07 is in compliance with that in the Council Directive 75/440/EEC.

Over the period considered, water flow was measured when collecting water samples. The data sets collected in the base can be used to assess the loads discharged from the neighbour countries and the loads entering and leaving the study area.

The analysis of potential threats due to excess concentrations of nitrates was carried out for the whole 11-year set and for each year separately. Assessments are based on the maximal concentrations of nitrates that occurred in the data sets for the cross-section (KOROL et al., 2002; 2003). When the maximal values exceeded $40 \mathrm{mg} \mathrm{NO} \cdot \mathrm{dm}^{-3}$, the period when excess values occurred was analysed in detail and the causes of occurrence were established. 
Table 4. Comparison of the number and \% of nitrate concentrations within the thresholds of water quality classes between 1992 and 2005

\begin{tabular}{|c|c|c|c|c|c|c|c|c|c|c|c|}
\hline \multirow{3}{*}{ Year } & \multirow{3}{*}{$\begin{array}{c}\text { Number } \\
\text { of data }\end{array}$} & \multirow{2}{*}{\multicolumn{2}{|c|}{$\begin{array}{l}\text { Concentration } \\
\mathrm{mg} \mathrm{NO}_{3} \cdot \mathrm{dm}^{-3}\end{array}$}} & \multicolumn{4}{|c|}{ Number of data in ranges } & \multicolumn{4}{|c|}{$\%$ of data } \\
\hline & & & & \multicolumn{8}{|c|}{ ranges of concentrations, $\mathrm{mg} \mathrm{NO}_{3} \cdot \mathrm{dm}^{-3}$} \\
\hline & & Min. & Max. & $\leq 25$ & $\leq 40$ & $\leq 50$ & $>50$ & $\leq 25$ & $\leq 40$ & $\leq 50$ & $>50$ \\
\hline 1992 & 2434 & 0.04 & 102.6 & 2258 & 127 & 20 & 29 & 92.76 & 5.22 & 0.82 & 1.20 \\
\hline 1993 & 1318 & 0.04 & 100.9 & 1293 & 20 & 3 & 2 & 98.10 & 1.52 & 0.23 & 0.15 \\
\hline 1994 & 1381 & 0.04 & 107.9 & 1280 & 76 & 12 & 13 & 92.68 & 5.50 & 0.87 & 0.95 \\
\hline 1995 & 1357 & 0.04 & 159.3 & 1293 & 48 & 8 & 8 & 95.28 & 3.54 & 0.59 & 0.59 \\
\hline 1998 & 934 & 0.35 & 70.70 & 879 & 42 & 8 & 5 & 94.11 & 4.50 & 0.86 & 0.53 \\
\hline 1999 & 931 & 0.18 & 76.98 & 869 & 48 & 5 & 9 & 93.34 & 5.16 & 0.54 & 0.96 \\
\hline 2000 & 723 & 0.49 & 102.1 & 670 & 39 & 5 & 9 & 92.67 & 5.40 & 0.69 & 1.24 \\
\hline 2001 & 707 & 1.73 & 66.36 & 661 & 36 & 2 & 8 & 93.50 & 5.09 & 0.28 & 1.13 \\
\hline 2002 & 716 & 0.31 & 57.07 & 673 & 36 & 6 & 1 & 93.99 & 5.03 & 0.84 & 0.14 \\
\hline
\end{tabular}

1999-2001 data used for specifying zones particularly vulnerable to pollution (PVZ) by nitrates from agricultural sources.

2004-2005 data obtained after implementation of remedial programmes in particularly vulnerable zones (PVZ). 


\section{RESULTS}

To find out whether the Middle Odra Basin really experienced the nuisance of water pollution with excess nitrate concentrations, a global assessment was carried out for the time period of 1992-2005. The results showed that the lotic surface waters of the Middle Odra Basin are only slightly polluted with nitrates. High purity water, clean water and water vulnerable to pollution accounted for $94.62 \%, 4.15 \%$ and $0.58 \%$ of the samples, respectively, while the percent of water vulnerable to pollution, where the concentrations of nitrates exceeded $50 \mathrm{mg} \mathrm{NO}_{3} \cdot \mathrm{dm}^{-3}$, amounted to $0.65 \%$ only. In particular years the percent of concentrations exceeding the standard value varied from $0.08 \%$ to $1.24 \%$ (Table 4 ).

The results have also shown that the quality of surface waters used for municipal supply complied with the standards set in the Decree of the Ministry of Environment of 27 November 2002. This should be attributed to the implementation of the Council Directive 75/440/EEC.

As can be inferred from the detailed analysis of the results obtained at 49 monitoring stations in 1998, 1999 and 2003, 2004, 2005 (Table 5), water polluted with nitrates was detected in the basins of only two tributaries of the Middle Odra: in the Bystrzyca and Barycz (below the discharge of polluted waters from the Orla and Kopanica) The results obtained in 2003 revealed that the water of the Bóbr in the source area was polluted by nitrates discharged from the territory of the Czech Republic.

Table 5. The highest nitrate concentrations recorded at the monitoring stations of the Middle Odra and the assessment of eutrophication processes observed in these waters

\begin{tabular}{|c|c|c|c|c|c|c|c|}
\hline \multirow{2}{*}{ River } & \multirow{2}{*}{$\mathrm{Km}$} & \multirow{2}{*}{ Monitoring station } & \multicolumn{5}{|c|}{ Max. concentration, $\mathrm{mg} \mathrm{NO}_{3} \cdot \mathrm{dm}^{-3}$} \\
\hline & & & 1998 & 1999 & 2003 & 2004 & 2005 \\
\hline 1 & 2 & 3 & 4 & 5 & 6 & 7 & 8 \\
\hline Odra & 199.1 & above Brzeg Opolski & 19.47 & 21.59 & 15.30 & 16.10 & 13.86 \\
\hline Odra & 249.0 & Wrocław & 19.25 & 24.42 & 17.20 & 12.43 & 26.01 \\
\hline Oława & 2.0 & discharge into the Odra & 29.20 & 27.88 & 18.40 & 18.90 & 14.30 \\
\hline Ślęza & 2.4 & discharge into the Odra & 36.28 & 30.97 & 27.40 & 22.20 & 17.80 \\
\hline Bystrzyca & 88.4 & above Głuszyca & 5.97 & 5.58 & 5.70 & 5.13 & 6.15 \\
\hline Bystrzyca & 78.0 & above the Lubachów reservoir & 10.27 & 10.84 & 15.00 & 9.27 & 11.80 \\
\hline Bystrzyca & 74.1 & below the Lubachów reservoir & 38.98 & 42.88 & 43.80 & $\underline{67.40}$ & $\underline{66.20}$ \\
\hline Bystrzyca & 60.0 & above discharge of the Piława River & 26.15 & 24.21 & 48.70 & 33.50 & 37.00 \\
\hline Piława & 0.5 & discharge into Bystrzyca & 45.58 & $\underline{76.98}$ & 48.70 & $\underline{56.10}$ & $\underline{62.20}$ \\
\hline Bystrzyca & 50.7 & above the Mietków reservoir & 36.02 & $\underline{\mathbf{5 9 . 2 9}}$ & 43.40 & 43.50 & 33.10 \\
\hline Bystrzyca & 37.5 & below the Mietków reservoir & 17.21 & 17.48 & 21.90 & 14.30 & 21.39 \\
\hline Czarna Woda & 0.5 & discharge into the Bystrzyca & 27.43 & 37.61 & 25.50 & 16.80 & 17.11 \\
\hline Strzegomka & 0.2 & discharge into the Bystrzyca & 25.22 & 37.17 & 37.20 & 32.40 & 31.10 \\
\hline Bystrzyca & 12.8 & water gauge Jarnołtów & 21.68 & 28.76 & 21.40 & 18.40 & 20.90 \\
\hline
\end{tabular}


cont. table 5

\begin{tabular}{|c|c|c|c|c|c|c|c|}
\hline 1 & 2 & 3 & 4 & 5 & 6 & 7 & 8 \\
\hline Bystrzyca & 1.2 & discharge into the Odra & 21.24 & 28.76 & 23.60 & 18.10 & 19.37 \\
\hline Odra & 278.0 & above ZP “Rokita” (Brzeg Dolny) & 27.88 & 23.01 & 17.80 & 19.40 & 16.47 \\
\hline Odra & 303.0 & below ZP "Rokita" & 22.12 & 21.68 & 18.60 & 18.60 & 17.85 \\
\hline Kaczawa & 3.2 & discharge into the Odra & 20.81 & 19.91 & 23.00 & 18.00 & 21.00 \\
\hline Odra & 330.0 & above Ścinawa & 18.14 & 23.45 & 19.90 & 20.00 & 17.00 \\
\hline Barycz & 115.2 & $\begin{array}{l}\text { above discharge of the Złotnica } \\
\text { River }\end{array}$ & 21.42 & 28.76 & 19.60 & 41.14 & 16.70 \\
\hline Barycz & 91.4 & above Milicz & 36.28 & 23.01 & 10.90 & 38.30 & 31.31 \\
\hline Barycz & 55.9 & above Żmigród & 32.30 & 20.35 & 11.60 & 37.00 & 26.75 \\
\hline Sąsiecznica & 0.5 & discharge into the Barycz & 24.78 & 19.47 & 13.90 & 26.90 & 28.52 \\
\hline Barycz & 36.6 & above discharge the Orla River & 25.75 & 19.47 & 12.40 & 33.00 & 25.00 \\
\hline Orla & 2.0 & discharge into the Barycz & $\underline{70.70}$ & $\underline{58.85}$ & 38.50 & $\underline{79.00}$ & $\underline{75.00}$ \\
\hline Kopanica & 1.0 & discharge into Barycz & $\underline{58.67}$ & $\underline{63.27}$ & $\underline{62.00}$ & 18.10 & 29.80 \\
\hline Barycz & 1.0 & discharge into the Odra & $\underline{56.90}$ & 48.67 & $\underline{55.70}$ & 28.10 & 32.50 \\
\hline Odra & 382.5 & below discharge of the Barycz & 23.45 & 23.01 & 25.60 & 21.00 & 19.00 \\
\hline Odra & 428.8 & above Nowa Sól & 23.89 & 21.33 & 22.60 & 22.20 & 18.46 \\
\hline Odra & 511.0 & above discharge of the Bóbr River & 19.25 & 25.00 & 19.20 & 17.30 & 17.40 \\
\hline Bóbr & 269.6 & boundary monitoring station & 12.35 & 15.31 & $\underline{82.40}$ & 21.79 & 15.32 \\
\hline Bóbr & 248.0 & $\begin{array}{l}\text { above discharge of the Zadrna } \\
\text { River }\end{array}$ & 8.32 & 9.07 & 9.10 & 11.60 & 9.70 \\
\hline Bóbr & 212.7 & above Jelenia Góra & 12.12 & 12.21 & 10.80 & 13.42 & 14.22 \\
\hline Bóbr & 205.1 & above "Celwiskoza" & 9.82 & 10.71 & 9.40 & 9.43 & 12.84 \\
\hline Bóbr & 191.9 & below the "Pilchowice" reservoir & 10.18 & 10.35 & 9.60 & 12.09 & 16.70 \\
\hline Bóbr & 167.7 & above Lwówek Śląski & 11.95 & 11.90 & 10.90 & 12.58 & 18.16 \\
\hline Bóbr & 143.5 & above Bolesławiec & 12.43 & 12.39 & 11.30 & 12.36 & 16.74 \\
\hline Bóbr & 127.0 & $\begin{array}{l}\text { below discharge of the Bobrzyca } \\
\text { River }\end{array}$ & 12.61 & 12.65 & 11.80 & 12.67 & 16.78 \\
\hline Bóbr & 111.2 & above Leszno Górne & 8.85 & 10.84 & 11.90 & 13.20 & 15.60 \\
\hline Bóbr & 90.0 & $\begin{array}{l}\text { below discharge of the Szprotawa } \\
\text { River }\end{array}$ & 9.73 & 7.96 & 11.20 & 13.08 & 15.10 \\
\hline Kwisa & 4.4 & discharge into the Bóbr & 7.96 & 9.34 & 13.50 & 10.00 & 14.00 \\
\hline Bóbr & 77.4 & above Żagań & 8.85 & 8.72 & 12.60 & 13.90 & 16.10 \\
\hline Bóbr & 47.9 & Nowogród Bobrzański & 8.85 & 8.94 & 11.20 & 13.70 & 15.20 \\
\hline Bóbr & 2.0 & discharge into the Odra & 8.41 & 8.85 & 9.80 & 13.60 & 13.80 \\
\hline Odra & 530.6 & Połęcko (boundary) & 19.91 & 20.88 & 23.70 & 19.38 & 22.60 \\
\hline Odra & 552.0 & above Eisenhüttenstadt (boundary) & 20.13 & 26.37 & 19.00 & 19.49 & 25.26 \\
\hline Odra & 566.0 & below Eisenhüttenstadt (boundary) & 19.51 & 24.82 & 19.50 & 18.42 & 23.23 \\
\hline Odra & 581.0 & above Słubice (boundary) & 21.33 & 20.62 & 17.80 & 19.40 & 23.09 \\
\hline Odra & 615.0 & $\begin{array}{l}\text { above discharge of the Warta } \\
\text { (boundary) }\end{array}$ & 21.42 & 23.63 & 18.30 & 18.38 & 23.40 \\
\hline
\end{tabular}


When analysing the sources of pollution of the Piława and Bystrzyca waters, it became obvious that nitrates enter the riverine water with the effluents from municipal sewage treatment plants. It is believed that the planned modernisation of the plants will upgrade the efficiency of nutrient removal and thus reduce the pollution of the said rivers. The assessment of sources of high nitrate concentrations in the Barycz and its tributaries (Orla and Kopanica) measured in the years 1998-2001 (i.e. before the zones particularly vulnerable to pollution by nitrates from agricultural sources were specified) showed that these pollutants came from agricultural activity. Based on the so obtained data the Orla and Kopanica Basins (Figure 2) were defined as particularly vulnerable zones where nitrogen discharge from

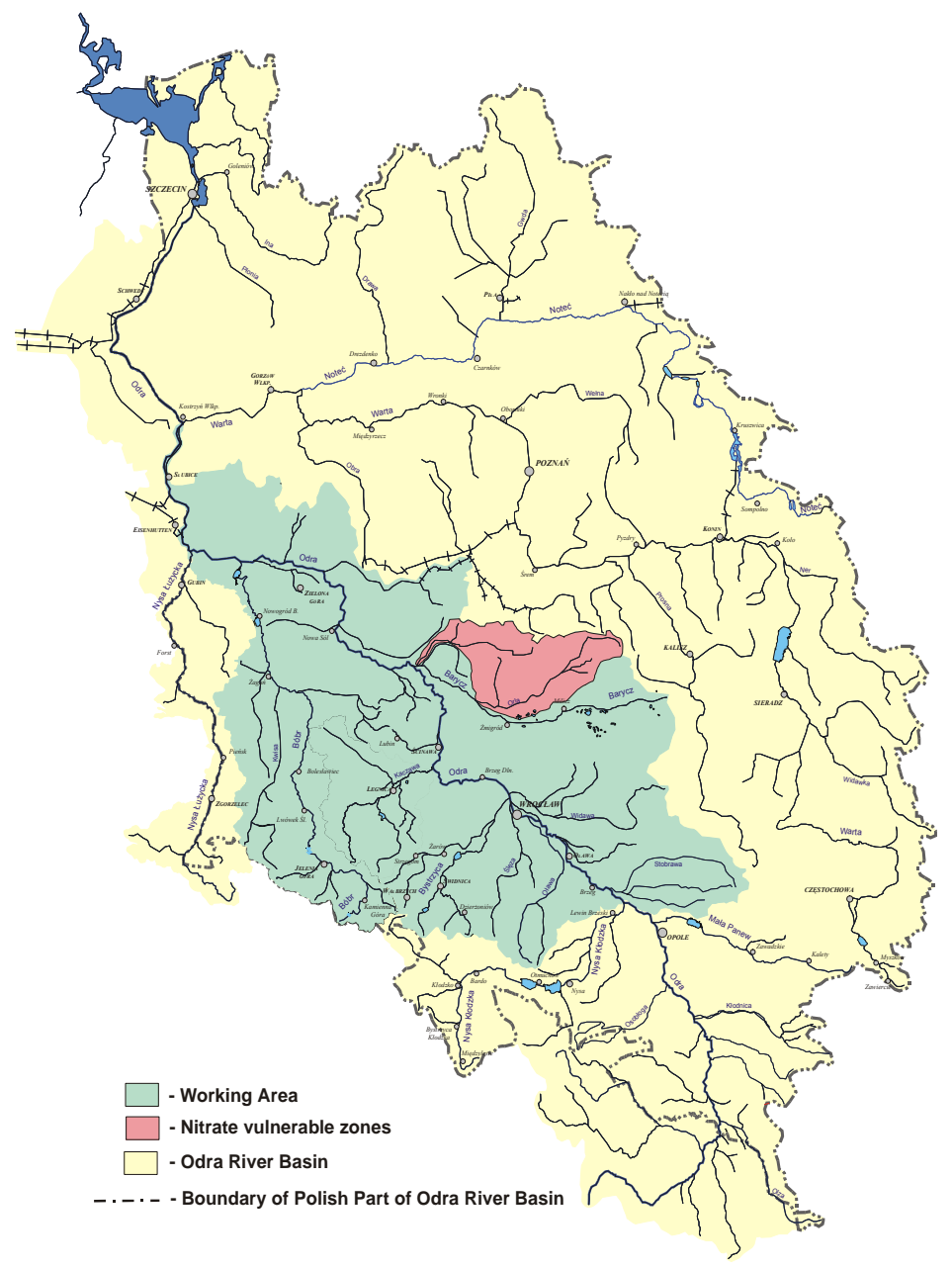

Fig. 2. Map of the Middle Odra with vulnerable zones from which nitrogen discharge from agricultural sources should be limited 
agricultural sources must be reduced (Rozporządzenie Dyrektora RZGW, 2004; Rozporządzenie MŚ z dnia 23 grudnia 2002 r.). In 2003 additional monitoring of nitrates was implemented at 19 stations on the Orla and 8 stations on the Kopanica. Maximum concentration in the Orla and its tributaries were $110.9 \mathrm{mg} \mathrm{NO}_{3} \cdot \mathrm{dm}^{-3}$, that in the Kopanica $-87.4 \mathrm{mg} \mathrm{NO}{ }_{3} \cdot \mathrm{dm}^{-3}$. The results allowed for the conclusion that the excess of riverine water pollution with nitrates was observed in spring (March, April) and autumn (September, October); in the other seasons the concentrations of nitrates did not exceed $10 \mathrm{mg} \mathrm{NO} \mathrm{Nm}_{3}^{-3}$. Monitoring data recorded in 2004 and 2005 showed that the concentrations of nitrates in the Orla did not change while those in the Kopanica and Barycz decreased notably and did not exceed $40 \mathrm{mg} \mathrm{NO}_{3} \cdot \mathrm{dm}^{-3}$. This finding indicates that the remedial actions were successful only in the Kopanica Basin and contributed also to the reduction of nitrates in the Barycz.

Analyses of the river water for the presence of nitrates were accompanied by eutrophication assessments. According to the data obtained for the investigated rivers in 2003-2005, eutrophic river waters were detected at 32 out of the 49 monitoring stations. What seems to be of particular significance is that eutrophication occurred along the entire length of the Odra River. As for the tributaries, only the Oława and the Bóbr were not eutrophic (Table 5). Other tributaries showed eutrophication processes only in their middle and lower parts; the spring parts in mountainous areas being non-eutrophic.

\section{CONCLUSIONS}

Obtained results enable the following conclusions to be formulated:

1. The data set from river water monitoring obtained so far is sufficient for assessing the vulnerability to nitrates and the extent of eutrophication.

2. In river basins where surface water is taken for water supply systems, the water quality is very high and maximum concentrations of nitrates fall below $25 \mathrm{mg} \mathrm{NO} \cdot \mathrm{dm}^{-3}$.

3. In the Middle Odra Basin, river water pollution with nitrates is very low: high purity waters, clean waters and water vulnerable to pollution accounted for $94.62,4.15$ and $0.58 \%$ of the samples, respectively; water samples where nitrate concentrations exceeded $50 \mathrm{mg} \mathrm{NO} \cdot \mathrm{dm}^{-3}$ accounted for $0.65 \%$. In particular years the percent of concentrations that exceeded the levels set by relevant standards varied from 0.08 to $1.24 \%$.

4. With the results obtained it was possible to determine zones particularly vulnerable to pollution with nitrates from agricultural sources. These zones are in the Barycz Basin and cover:

- the Orla Basin of a surface area of $1546.5 \mathrm{~km}^{2}$;

- the Rów Polski (Kopanica) Basin of a surface area of $827.6 \mathrm{~km}^{2}$. 
5. The occurrence of eutrophication processes was detected in 32 out of 53 monitoring stations. Eutrophic waters occurred along the entire length of the Odra. Of the Odra tributaries, only Oława and Bóbr were not eutrophic; other tributaries were free from eutrophication processes only in the source areas.

6. To provide appropriate execution of the programme that enables the control of surface water pollution by nitrates, as well as the control of eutrophication processes, it is necessary to establish a monitoring network carrying out a precisely defined research programme. This monitoring system must be linked to a network that is capable to measure the water flow, thus enabling nutrient balances to be established in specified measuring and control cross-sections. The once-a-month frequency of sampling can be regarded as sufficient only for rivers carrying high purity and clean waters. Vulnerable waters, as well as water polluted with nitrates, should be sampled with a higher frequency

\section{REFERENCES}

1. Council Directive 91/676/EEC of 12 December 1991 concerning the protection of waters against pollution caused by nitrates from agricultural sources. O. J. L 375 31.12.1991: 1.

2. Council Directive of 16 June 1975 concerning the quality required of surface water intended for the abstraction of drinking water in the Member States (75/440/EEC). O. J. L 194 25.07.1975: 26.

3. Directive 2000/60/EC of the European Parliament and of the Council of 23 October 2000 establishing a framework for Community action in the field of water policy. O. J. 327 22.12.2000: 72.

4. KOROL R. et al., 2002. Wyznaczenie wód powierzchniowych i podziemnych wrażliwych na zanieczyszczenia związkami azotu ze źródeł rolniczych oraz obszarów szczególnie narażonych, z których odpływ azotu ze źródeł rolniczych należy ograniczyć w granicach RZGW we Wrocławiu. (Estimation of surface and ground waters sensitive to pollution by nitrogen compounds from agricultural sources and particularly sensitive areas from which nitrogen outflow from agricultural sources should be limited within the borders of the Regional Water Management Board in Wrocław). Wrocław, IMGW maszyn.

5. Korol R. et al., 2003. Wykaz wód powierzchniowych, które są lub mogą być w przyszłości wykorzystywane do zaopatrzenia ludności w wodę przeznaczoną do spożycia. (A list of surface waters which are or could be used in the future as the sources of drinking water). Wrocław, IMGW maszyn.

6. Oder-Auen-Atlas, 2000. WWF Deutschland.

7. Podział hydrograficzny Polski. (Hydrographic division of Poland). 1983. Warszawa, IMGW.

8. Report for the International River Basin District Odra on the implementation of Art. 3, Annex I of the Directive 2000/60/WE of the European Parliament and the Council of the 23rd of October establishing a framework for Community action in the field of water policy O.J. L 327, 22.12.2000). 2004. Intern. Comm. Protect. Odra Poll.

9. Rozporządzenie Dyrektora Regionalnego Zarządu Gospodarki Wodnej we Wrocławiu z dnia 10 grudnia 2003 r. w sprawie określenia wód wrażliwych na zanieczyszczenie związkami azotu ze źródeł rolniczych oraz obszarów szczególnie narażonych, z których odpływ azotu ze źródeł rolniczych należy ograniczyć. (Directive of the Director of the Regional Water Management Board in Wrocław of December 102003 on the estimation of waters sensitive to pollution by nitrogen compounds from agricultural sources and particularly sensitive areas from which nitrogen outflow from agricultural sources should be limited) Dz. U. Woj. Dolnośl. z 07.01.2004 nr 2 poz. 38. 
10. Rozporządzenie Ministra Środowiska z dnia 27 listopada 2002 w sprawie wymagań, jakim powinny odpowiadać wody powierzchniowe wykorzystywane do zaopatrzenia ludności w wodę przeznaczoną do spożycia. (Directive of the Minister of Environment of November 272002 on the requirements that should be met by surface waters used as sources of drinking water). Dz. U. nr 204 poz. 1728.

11. Rozporządzenie Ministra Środowiska z dnia 23 grudnia 2002 r. w sprawie kryterium wyznaczania wód wrażliwych na zanieczyszczenia związkami azotu ze źródeł rolniczych. (Directive of the Minister of Environment of December 232002 on the criteria for estimating waters sensitive to pollution by nitrogen compounds from agricultural sources). Dz. U. nr 241 poz. 2093.

12. Rozporządzenie Rady Ministrów z 10 grudnia 2002 r. w sprawie przebiegu granic obszarów dorzeczy, utworzenia regionalnych zarządów gospodarki wodnej oraz podziału obszarów dorzeczy na regiony wodne. (Government order of December 10, 2002 on the route of catchment borders, on establishment of regional water management boards and on catchment division into water regions) Dz. U. nr 232 poz. 1953.

\section{STRESZCZENIE}

\section{Ocena zanieczyszczenia azotanami wód w dorzeczu Odry Środkowej}

Słowa kluczowe: azotany, dorzecze Odry Środkowej, eutrofizacja, jakość wód, obszary szczególnie narażone na zanieczyszczenie azotanami z rolnictwa

W pracy przeanalizowano wyniki opracowanej charakterystyki stanu jakości wód powierzchniowych, stanowiącej podstawę do określenia wód wrażliwych na zanieczyszczenia związkami azotu ze źródeł rolniczych oraz wyznaczenia obszarów szczególnie narażonych, z których odpływ azotu ze źródeł rolniczych należy ograniczyć. Szczegółowo scharakteryzowano zawartość związków azotu w wodach powierzchniowych na obszarze dorzecza Środkowej Odry, oceniono stopień eutrofizacji śródlądowych wód powierzchniowych płynących, w których czynnikiem decydującym jest azot. Przedstawiono wyniki wyznaczania wód powierzchniowych wrażliwych na zanieczyszczenia (zanieczyszczonych oraz zagrożonych zanieczyszczeniem) związkami azotu ze źródeł rolniczych i określono obszary szczególnie narażone, z których odpływ azotu ze źródeł rolniczych należy ograniczyć. Wyniki przedstawiono w ujęciu tabelarycznym i na rysunkach.

Reviewers:

Dr. Ralf Dannowski

Dr. Ireneusz Kajewski 